\title{
Apostolicity as Divine Attribute in Trinitarian Relationship: the origin and nature of apostolicity and how it is demonstrated
}

\author{
Dr Erwin Samuel Henderson \\ Independent Theological Researcher \\ Chemin de la Mayre Rousse 26700 \\ Pierrelatte, France \\ E-mail: erwin@apokatalasso.com \\ https://orcid.org/0000-0001-7180-3108
}

Doi: https://doi.org/10.46222/pharosjot.102.020

\begin{abstract}
This paper responds to the question what is the origin and nature of apostolicity and how it is demonstrated? The investigation examines the meaning of apostolicity found in the New Testament, its significant transition through the post-apostolic period, and the consequence on contemporary understanding. The dilemma of the first and second century-generation Christians was how to understand apostolicity in light of the disappearance of the 'sacred triad' (apostles, prophets and teachers). The emerging principles of discontinuity, transference, transformation and succession carved the road to canonisation, bishop-centrism and episcopal systemisation. The Pentecostal anchorage in the outpouring of the Spirit at Pentecost is determinant in qualifying apostolicity; while emphasising agency and function, it also turns attention to the Person of the Spirit. This leads necessarily to an examination of the Trinity, ontologically and relationally, and therefore brings a fuller response to the research question. Subsequent exploration of the non-hierarchical, 'intra-Trinitarian' relationship will demonstrate an apostolic archetype. This contribution seeks to restore the Trinity to apostolic thinking in response to the historical construct by defining the nature of apostolicity in Godhead, and to argue apostolicity as a response to subordinate suppositions. It concludes with a proposed basis for renewed self-understanding as Trinitarian extension.
\end{abstract}

Keywords: apostolicity, Trinity, ontology, episcopate, Pentecostalism.

\section{Introduction}

In constructing a response to the question what is the origin and nature of apostolicity and how it is demonstrated, this article examines the significant historical junctures: the apostolic dilemma of continuity and discontinuity; the post apostolic period solutions of canonisation, the bishop-episcopate office and construct; and contemporary ecumenical, Pentecostal and Charismatic developments that weigh directly upon understanding and praxis of apostolicity. The response will lead to the anteriority of apostolicity within the Trinity and argues for an 'old yet new' paradigm. The proposition for continuity that will be set out, introduces a new lexicon based on terms such as: ontology, relationality and operationality.

\section{Methodology}

Knowledge sources were gathered from biblical, patristic, contemporary and Pentecostal theological writings and bible exegesis, significant and relevant to the research problem. The validity of this theological context is to accurately represent and articulate historical and theological formulation of apostolicity to establish correlation to the research inquiry. The 
scholarly theological writings chosen and consulted provide authoritative insights into the interpretive issues and developments that explicate the contemporary viewpoint and discussion on theology and praxis. Based upon the identified interpretive outcomes, the response to the research question articulates the significance of an ontological Trinitarian apostolic perspective which contributes its particularities to the body of current knowledge on this subject.

\section{The Apostolic Dilemma}

The significance of apostles for apostolicity, directs attention to the twelve called apostles, the sent ones, beginning with Jesus, ${ }^{1}$ relying upon the historical mandating of the twelve by Jesus to accompany, learn, and experience Him 'apostolically'. Kelly (1968: 31) suggests, "if He (Christ) was the supreme teacher, the immediately accessible authorities both for the facts about His Person and for His message were (a) the prophets, who had foreseen every detail of His ministry, and (b) the apostles, who had worked with $\mathrm{Him}$ and whom $\mathrm{He}$ had commissioned." This extends to the 'sacred triad' of apostles, prophets and teachers, as referred to by Harnack, (1962: 277) who draws attention to their particular charismatic characteristics: appointed by God, assigned to the whole church, and discharging a direct command from the Spirit (1962: 280). All of which finds confirmation in the Didache (Roberts: Ch.Xi; Harnack, 1962: 279). ${ }^{2}$ Müller characterises further the uniquity of the apostles, as having direct personal knowledge and experience of Jesus and his words, as bearers of the inaugural Pentecostal Holy Spirit baptism, as representative of particular authority in primitive Christianity and as guardians of the true tradition traced back to the historical figure of Jesus (Brown, 1975: 129). The patristic fathers such as Justin (100-c.-165 CE) (Kelly, 1968: 33) and Eusebius (265$339 \mathrm{CE}$ ), witness to the importance of this endorsement by seeking source in the original apostles, as the means to legitimise and authenticate (McKechnie, 2001: 105).

In the light of the apostles' uniqueness, the apostolic dilemma appears dual faceted: firstly, by discontinuity, how could the post apostolic period continue the apostolic expression central to early Christianity? The second facet is the necessity of guaranteeing the continuity of the authoritative apostolic foundations in light of this. In contrast, apostolic discontinuity, formulated by Boice (1986: 611) stands firmly on cessationist grounds: "neither one of these gifts exists today. We no longer have apostles or prophets in that sense ... those who spoke from God have left us the New Testament." Ferguson, Wright (1988: 40) accentuate discontinuity by emphasising a first century eyewitness phenomenon, "incapable of repetition or succession." However, Müller (Brown, 1975: 132) qualifies the dilemma with the terms 'limitation' or 'transference' as means of continuity.

To understand the historical process that led to discontinuity, Harnack (1962: 286) helpfully outlines the demise of the 'sacred triad' which the apostolic dilemma engendered. By the midsecond century in the time of Origen (185-c.-256), the name of apostle had become scarce. Come the end of the second century, the prophets were deemed complete, as Josephus (Whiston, ed. 1987: 776) states "... there has not been during this time an exact succession of prophets," of the Hebrew bible, writing sometime after 93CE. Harnack (1962: 273) believes this position transferred into the church, considering "the 'succession of the prophets' at an end." ${ }^{3}$ The rise of the Montanist 'New Prophecy' movement ${ }^{4}$ caused a schism with orthodox

\footnotetext{
${ }^{1}$ Hebrews 3:1

${ }^{2}$ Early Christian Writings, Didachē, Ch.11. Accessed 17th May 2021.

http://www.earlychristianwritings.com/text/didache-roberts.html.

${ }^{3}$ Harnack finds confirmation in Eusebius: H.E., iii., 10. 4.

${ }^{4}$ Montanism 'New Prophecy' movement (McKechnie, 2001: 171) composed of further Spirit revelation beyond the apostolic repository, through ecstatic possession and a form of direct dictation of the Spirit in which the speaker was passive, said to be imported from Montanus' strong gift of ecstasy from heathenism (Wand, 1937: 57, 59). While widely influenced Phrygia and Africa through Tertullian, for a generation (Ferguson, Wright, 1988: 444-45).
} 
catholicity and "... brought early Christian prophecy at once to a head and to an end ..." (1962: 289 ), rendering prophets irrelevant to church and of isolated rarity. Likewise, the teachers and teaching also disappeared around the early fourth century (1962: 294). The continuity of this apostolic and charismatically defined ministry crisis underwent transformation by means of: firstly, Greek philosophical schools taking mainstage by integrating Christian teaching; secondly, the transference of the 'sacred triad' to bishop-clergy office, which produced an episcopal catechetical systematic body of teaching. This, in Harnack's (1962: 296) words, "... was due to the episcopate with its intolerance of any office that would not submit to its strict control ..."

This historical process demonstrates the necessary factors of discontinuity, transference, transformation and succession, to substantiate the paradigm shift induced by this apostolic dilemma, "... one has before one's eyes the start and the goal of one of the most important developments in early Christianity" (1962: 284). Brown (1975: 135) perceives the transformation of apostolicity as a "... decisive influence in preventing the disintegration of the witness to Christ and maintaining the continuity of its tradition down to the time when the canon of the NT was fixed." On the basis of these concepts, subsequent 'forms' of apostolicity would appeal to 'apostolic origin' for legitimacy.

\section{Post Apostolic Solutions}

The apostolic dilemma therefore found resolution in canonisation and bishop-centricity, foundational to the emerging episcopal innovation. To set the scene in the pre-catholic, (Harnack, 1962: 335) ${ }^{5}$ pre-episcopalian construct, Ferguson, Wright (1988: 40-41) portray the essence of post New Testament apostolic practice,

The apostolic fathers find the solutions to the problems of their day in faithful dependence upon the tradition of the church ... handed down to them by ... the apostles themselves ... grappling with the concrete problems of the day, using Scripture, the sayings of Jesus, and the tradition of the apostles ... to consolidate the faith and practice of the church and to be faithful to what they had received...

\section{Apostolicity and Canonisation}

The canonisation of apostles and apostolic witness was the principal means of preserving the unique and direct testimony deposited in the apostles. However, mutation was required for continuity to resolve the figure of the apostles as much as the oral-written apostolic repository. As Irenaeus (130-c.-200) says, "what the apostles at first proclaimed by word of mouth, they afterwards by God's will conveyed to us in Scriptures ..." (Kelly, 1968: 38). Irenaeus' thought is more than the creation of written record of apostolic tradition, "... as an institutional vehicle for transmitting the legacy of the first disciples of Jesus ..." (McKim, 1998: 5) it signifies the transference of apostolicity from the apostles to the written record containing the apostolic testimony (Kelly, 1968: 38). As such, the apostles who " ... provided a normative interpretation of the person and work of Christ and a normative repository of his teaching ..." (Gaebelein, 1979: 633) became Canon. Thereafter, the norm of apostolicity was contained to living by their teaching, enshrined in the NT Scriptures (Ferguson, Wright, 2008: 40). Karkkainen (2001: 324)

Eusebius is scathing in condemnation towards the personage and practices, was it truly devil or Spirit possession? (Bettenson, 1963: 77). Combined with the affirmation of their being further revelation after Christ, something more than Christ. Tertullian contextualises using John 16.12-13. The prophetic phenomenon, however legitimate, was condemned and eventually petered out (Ferguson, Wright, 1988).

5 "The apostolicity expressed through the apostles, prophets and teachers, given to the whole church set the context for catholicity materialized through Canon and took the episcopate ... it is not unsuitable to speak of precatholic and catholic Christianity" Harnack, A, 1962: 335. The Mission and Expansion of Christianity. 
in his exposition of Pentecostalism and apostolicity, acknowledges this "faithfulness to the apostolic doctrine and life." Apostolic discontinuity therefore finds continuity through transference of the person and testimony of the apostle to canon, as a result the figure and their identifiable characteristics were no longer valid.

Three immediate consequences result from this transference:

Firstly, canonisation created the void of depersonalised apostolicity which would in turn also undergo reinterpretation.

Secondly, a shift in authority: for first generation Christians, "the threefold nature of authority - the Lord, the Scriptures of Israel, the apostles" underwent a process of radical remodelling with the emergence of the New Testament canon. Karkkainen (2001:335) observes, "the canonical New Testament can be reckoned as the 'strict successor' to the apostles..." Universal apostolic authority was transferred to written scripture, after the disappearance of the 'sacred triad', also ensuring universal acceptance (Gaebelein, 1979: 635).

Thirdly, the shift from apostolicity to canon engendered, catholicity or universality (Gaebelein, 1979: 635). In a context of apostolic mission 'to the ends of the earth', catholicity was founded upon the commonality of beliefs and practices in church which were considered to reflect truth and 'the true church' (Harnack, 1962: 334-35). This primitive form of catholicity federated "... the rule of faith, by a common possession and interpretation of old Scripture, and by a shared willingness to celebrate the gospel event..." (McKim, 1998: 5).

Harnack (1962: 394) provides a threefold progression, "the apostles' creed, the apostolic canon, and belief in the apostolical succession of the episcopate." He infers the correlation of apostolic orality with canon as the means to empowering the episcopate construct with apostolic legitimacy. In light of the significance of the transference in authority, the same author proposes 'pre-catholic' and 'post catholic' categories to distinguish the transmutation of apostolicity during the early post-apostolic period. The point being, the greater the extent of transformation, the greater the degree of distanciation from the original apostolic figure and direct testimony.

\section{Apostolicity and Bishop-centricity}

Having secured apostolic and catholic canon, it was one small step further to acquire the administration of the canon; succession and transference ensured the continuity of this new construct whereby bishop-centricity firmly succeeded the original apostles and established a new relationship to apostolic tradition and the churches. Clement (c.88-97 or 92-101), writing at the end of the first century implies, "...that the hierarchy which succeeded the apostles inherited the gospel message." According to Kelly (1968: 35), the book of second Clement imposes "a strict obedience to the presbyters ... (as) their instructions are identical with those of Christ Himself." The transference of apostolic identity to bishop office, which secured position and authority through succession, was established upon the apostolic tradition and creed. Irenaeus, (130 c.-200) affirms, "tradition which is derived from the Apostles, ... is safeguarded in the churches through the successions of presbyters ... appointed bishops in the churches by the Apostles, and their successors (or successions) down to our own day ..." (Bettenson, 1963: 68-69). Ignatius of Antioch (c.†110), his contemporary, refers to the bishop as "the appointed guarantor of purity of doctrine" (Kelly, 1968: 35). Cyprian (c.200-258), championed bishop-centricity, and an "advanced theory of apostolic succession" (Ferguson, Wright, 2008: 184). He affirms that the command of Christ was "the office of bishop and the episcopate system of Church." His bishop-centricity led to a fundamental Christological error whereby, "the bishop is in the Church and the Church in the bishop" (Bettenson, 1963: 73-74). The paradox of this transference from apostle to bishop was the emptying of the substance of 
the apostolic; Harnack (1962: 369-70) concurs, "they were not equal to their predecessors ... nor could they certify themselves ... by means of miracles, while in many other respects they showed their inferiority." The association with apostolic appellation became burdensome for the episcopal construct.

In the midst of these voices claiming succession, there were two which stood out emphasising the significance of apostolic origins, even though they were absorbed by the logic of the successional construct. Firstly, Tertullian (160-C.-220) draws out the significance of inherent origins of kind, "every kind of thing must needs be classed in accordance with its origin." His point is that apostles' plant apostolic churches, from which other churches derive, which are apostolic 'offspring'. This would however, be interpreted contextually as legitimate continuity through transference, transformation and succession. Secondly, Irenaeus (130-c.-200), stating "what the churches received from the Apostles, the Apostles from Christ and Christ from God" (Harnack, 1962: 70-71), was a rare voice pointing to theocentric origins. For both of them, Christ was the ultimate source of Christian origins, "being the truth, the Word by Whom the Father had been revealed; but He had entrusted this revelation to His apostles" (Kelly, 1968: 36).

In summary, bishop-centricity having secured apostolic succession, through transference and transformation, claimed apostolic origin and legitimacy by instituting forms of meditation. As theologian Karkkainen (2001: 324) aptly summarizes, the key historical issues of apostolicity are a question of ecclesiology. Succession leads to mediation through the ordained bishop and office, the sacramental liturgies and "performance of objective activities." In this, Christ and his church are recognised legitimately and historically as 'apostolic'. ${ }^{6}$ Contrariwise, reflecting origins and kind, Brown (1975: 132) affirms that the "NT never betrays any understanding of the apostolate as an institutionalized church office, capable of being passed on." Therein lies a consequence of the dilemma whereby apostolicity only finds expression through mediatory persons, means and actions. This distanciation from source raises an objection, as to the origin of and relationship to apostolicity decentred from Godhead, and defined functionally.

\section{Apostolicity and Contemporary Conceptions}

Contemporary conceptions of apostolicity are important to identifying the influence of the historical construct and the discontinuity-continuity dilemma in present day thinking. This implicitly embraces succession from the figures of the apostles, to the canon, to the bishop, to the episcopate philosophy and system of church, under the banner of "preserving the authentic apostolic testimony" (Kelly, 1968: 47). Campenhausen (Brown, 1975: 132) would place the origin of the apostolate in the primitive church. Karkkainen (2001: 327) from an apostolic missional perspective considers "the church's apostolicity means the sending out of the apostles to all humanity ... continued by the church." Hunter $(2013: 3,7)$ states that "apostolicity is frequently depicted by member churches of the $\mathrm{PWF}^{7}$ as continuity with the life, teachings and practices of the early Church." These three statements illustrate that it has become a logical next step to move to church designated functions and operations that manifest apostolicity as "'episcopocentric' ecclesiology". Herein lies the century-old tension between apostolic restorationism and catholic apostolicity, the latter building upon the episcopal hypothesis. Whether it be the post-denominational quest for 'reinvention' or the predenominational search for 'authenticity', likened to Harnack's pre- and post-catholic categories,

\footnotetext{
${ }^{6}$ Karkkainen, 2001, 326. Quote in Footnote 15 from Joint Lutheran-Roman Catholic Study Commission, \# 57 Malta Report [The Gospel and Church], 1972, (in, Growth in Agreement: Reports and Agreed Statements of Ecumenical Conversations on a World Level, eds. H. Meyer \& L. Vischer [New York/Ramsey, N.J.; Paulist and Geneva: WCC, 1984], pp. 168-89.

7 PWF: Pentecostal World Fellowship.
} 
they underscore the unease created by the discontinuity-continuity tension, felt within some Pentecostal spheres (2013: 10). ${ }^{8}$

Within the ecumenical dialogue on apostolicity, it is the correlation of practice, tradition and sacramental ritual, from within the church that are said to witness to apostolicity. Karkkainen (2001: 333-34) affirms the acceptability of "seven aspects of apostolicity" that concur with Hunter's (2013: 1) "uncontroversial aspects of apostolicity" in five broad facets. ${ }^{9}$ These aspects encapsulate the necessity of continuity: the life and faith of the apostles and apostolic New Testament church, of charismatic life and worship, of gospel mission, of vitality of life and discipleship. The implication is that replicating original apostolic practices guarantees fidelity in continuum. The normativity of apostolic Scriptures, of the whole people of God not only clergy, of the generational renewal of the Spirit and the Spirit alone rendering church apostolic relate to the process of ensuring succession on the basis of the historical view's parameters.

Contemporary apostolic networks differ in their significant attempt to recover the primitive apostolic origins: appointed by God, given to the church, equipped and commanded by the Spirit, this in face of the enduring episcopate construct and its effects. Kay's (2005: 160) writings on contemporary apostolic expressions consider the structural implications of the recovered missional emphasis on the apostle and apostolic natured networks. His analysis of missional bodies serves to emphasise the historicity of the underlying 'apostolic dilemma' as symptomatic in the present. The conclusion regarding denominational, interdenominational missions and networks portrays hierarchal, centralised and authoritarian control of all aspects of missionary and mission, "... and their hierarchies ran in precise parallel with the social stratification of the age ... only faith missions escaped the worst results of class-based governance." He summarises apostolic appellation through the following contrasts: relationality replaces hierarchal structures, divine charismatic gifts and ministries are primary over committees, boards, offices, and power struggles; authority and decision-making are recentred upon the nature of the divine vocation and equipping, rather than attachment to office, position or rank. The recovery of mission through the apostolic restoration has set mission, ministry within the church and along with these values, created a growth culture of reproductivity and multiplicity (2005: 163-64). This overview echoes the 'pre-denominational' search for the authentically apostolic by a return to source, reflective of the aspirations found in Pentecostal origins 'The Apostolic Faith Movement' (where) "the essence of it is to go back to the faith and experience of apostolic times to live consistently with the New Testament church ..." (Karkainnen, 2001, 330).

\section{Apostolicity and Pentecostalism}

Pentecostalism's rapport with apostolicity and episcopacy is reflected in the multiplicity of forms, functioning and ordering through which a plethora of expressions are found. Hunter (2013: 5) comments that there is "no uniform ecclesiastical polity embraced by Pentecostals..." As such, examples of bishop-centricity and episcopal succession and sacramentalism may be found, ${ }^{10}$ and on the other hand, the intention to live out of the original apostolic penetrates core beliefs. In contrast to the structural polarity, the understanding of the apostolic in the New Testament for Pentecostals is "more pneumatologically and charismatically loaded than most of the historical, or even more modern views ..." (Karkainnen, 2001: 327). The Pentecost

\footnotetext{
8 "The IPHC (International Pentecostal Holiness Church) has consistently affirmed bishops and sacraments as part of their identity." Hunter, H, Pentecostal Reflections on Apostolicity, EPTA Vol.33.1, 2013, 10.

${ }^{9}$ The five facets: fundamental identity with the church of Christ's apostles; the word of God lived out and understood in the apostolic tradition, guided by the Spirit; celebration of the sacraments instituted by Christ, practised by the apostles; continuity of its ministry; and being a missionary church. Quoting the World Council of Churches Faith and Order consultation (Chantilly 1985). Hunter, H, Pentecostal Reflections on Apostolicity, EPTA Vol.33.1, 2013, 1.

10 See footnote no.8.
} 
paradigm event bears primary significance apostolically as the origin and identity of the church, constituted by the Spirit (Vondey, 2017: 229-30).

Pentecostalism stands distinct in its understanding of succession, whereby office, formal ordination, and episcopal structuration are contrasted by an understanding of continuity clothed in spiritual experience. The historical construct of the dilemma through discontinuity, transference, transformation, and succession, finds here a measure of resolution. The Pentecostal continuity response to apostolicity is formulated as "the first apostles ministered in the power of the Spirit, and the focus of the early church's worship was the transmittance of the Spirit and a Spirited-experience" (Karkainnen, 2001: 327). The sustained pneumatological and charismatic life modelled by the apostles' teachings and practices, experienced in worship, gifts and 'empowered practice' replicate the constant and continued reality of experienced apostolicity $(2001: 248-49,238,243)$. One can speak of originality, "... because it shares in the experience of the anointing with the Spirit poured out on the apostles at Pentecost" (Vondey, 2017: 234). The universality of the Pentecost experience emphasises the reality for all believers, not only the community but the individual believer who is apostolic through the Spirit experience, standing in continuity with the original apostles $(2017: 249,244)$. While the theology is restorationist, Hunter (2013: 12) considers, "one would be hard pressed to say that any of the various ecclesial forms generated by the Pentecostal Movement truly espouse the priesthood of all believers." Pentecostal apostolicity does express reaction to the transmutations through the experientialism of original Spirit outpouring as grounds for apostolic expression in ministry and worship amid the challenge of individual apostolicity.

Karkainnen (2001: 332), rightly draws attention to restorationist perspectives, including some Pentecostals, who reduce the dilemma to a New Testament 'continuity' and historical church 'discontinuity' polarity. Admittedly the historical view requires the mutation principles outlined, however, this proposal argues that neither the restorationism of primitive apostolic practices, nor episcopal succession respond adequately to the research question of origins. The polarised argument is rendered invalid in view of the ontological Trinitarian construct.

\section{Apostolicity and Trinity}

Having examined the historical apostolic development through canonisation, bishop-centricity and the episcopate construct, and in order to answer the question, what is the origin and nature of apostolicity and how it is demonstrated, this section argues for postulating the nature of the Trinity and intra-Trinitarian relationality as the archetypal source of apostolicity. If the ingeneration of the Father, the generation of the Son and procession of the Spirit refer to the nature of the eternal existence of the Trinity, this strongly suggests that apostolicity originates in and defines Trinitarian being, relating and operating, from eternity to eternity (Schaff, 1885: 1325, 1344; Kelly, 1968: 267, 271).

\section{The Language of Apostolicity}

The Father, Son and Spirit are apostolic in that they are all 'Senders': the Father ${ }^{11}$ sends the Son, and sends the Spirit, ${ }^{12}$ the Son sends the Spirit, ${ }^{13}$ the Spirit sends the Son. ${ }^{14}$ The Father, the Son and the Spirit are apostolic in that they are all 'Comers': the Father and Christ come

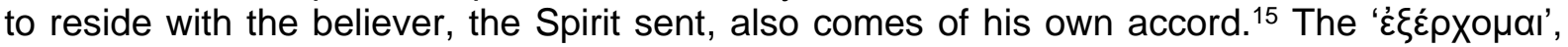
coming out of Christ, reflects neither the Father's apostolic mandate nor the relational sending,

\footnotetext{
${ }^{11}$ According to the biblical texts only the Father is not a 'Sent One'.

12 Son: John 8:42, 20:21; Romans 8:3; Galatians 4:4; Spirit: John 14:26; Galatians 4:6.

13 Luke 24:49; John 15:26; 16:7.

14 Isaiah 61:1; Luke 4:18.

15 Father: John 14:23; Son: John 12:44-46, 16:28; Spirit: John 15:26, 16:7.
} 
but instead, the autonomous choice of the Son to come, “... (they) have come to know in truth that I came from you; and they have believed that you sent me."16 This coming out is not generation from the person of God, rather it is the apostolic impulsion 'mapá' the Father. ${ }^{17}$ As much as Christ was sent by the Father and the Spirit, He came of his own impulsion (Henderson, 2019: 79). The procession of the Spirit is expressed in the same terms: He is

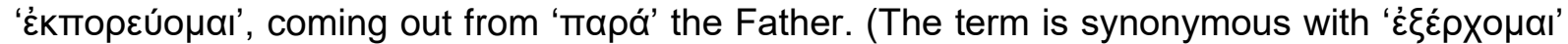
(Zodhaites, 1993: 553)). The former term is in the middle-passive voice while the latter term is primarily in the active voice. The procession of the Spirit thereby is a collaborative action of mutual agreement with the Father and the Son. The use of ' $\varepsilon x o \mu a$ ' $^{\prime}$ in the active voice, ${ }^{18}$

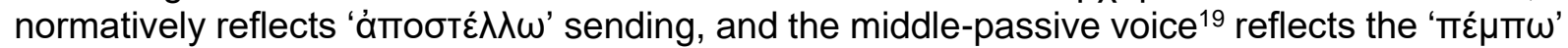
sending, thereby compounding the argument for the Trinitarian relational coming. It becomes evident that apostolicity is therefore raised out from functionality and agency into the realm of ontology and relationality intra-Trinity.

The use of the New Testament sending terms 'ámобтर́ $\lambda \lambda \omega$ ' and ' $\pi \varepsilon \dot{\mu} \mu \pi \omega$ ', considered as synonymous, (Brown, 1975: 128; Zodhaites, 1993: 1137), ${ }^{20}$ are applied to the sent ones; ${ }^{21}$ their meaning and use demonstrate the whole nature of apostolicity in Trinitarian relatedness. ${ }^{22}$ The generally accepted emphasis of 'ámообт́र $\lambda \lambda \omega$ ' in the act of sending is: authoritative, official and task-sphere orientated. However, Christ employs the terms to emphasise the origin and nature of the sender and sent one in 'mutual' relationship. ${ }^{23}$ The mandate or message is defined upon that primary basis, and whose purpose demonstrates the former. ${ }^{24}$ The use of the preposition 'व́mo' meaning source, indicates that any sending out from the Trinity bears explicitly the nature of that source. Apostolic attribute is therefore originated in God's nature, what proceeds from $\mathrm{Him}$ in word and in action permeates divine apostolicity, therein, who $\mathrm{He}$ is, is what $\mathrm{He}$ says, is what He does. ${ }^{25}$

' $\Pi \varepsilon \dot{\mu} \mu \omega \omega^{\prime}$ sending is more than synonymous, it defines relationally the nature of apostolicity. The meaning of accompaniment reinforced by the predominant participle $\operatorname{mood}^{26}$ advocates a continual actualised sending consciousness substantiated in Trinitarian relationality, "... He who sent me is with me. He has not left me alone..."27 Therein, inseparability is explained in apostolic terms.

Apostolic language therefore, not only proposes an explanation of the true nature of the sending of the Son and the Spirit from eternity revealed to the world, but also reveals the nature of intra-Trinitarian relationship.

\footnotetext{
16 John 17:8 (ESV).

17 Only three times in the New Testament ' $\varepsilon$ ' is employed apostolically regarding the Spirit and Jesus' relationship to the Father: John 8:42 of Jesus; 1Corinthians 2:12; 1John 4:2. While emphasising origin the term can be read as coming out from a place and as such concords with John's use of ' $\pi \alpha \rho a ́$ '.

18 John $1: 11,7: 28,8: 42,16: 28 ; 15: 26$.

19 John 1:9, 3:31, Jn.14:23; 16:13.

20 The latter distinguishes to send generically with authority retained whereas 'ómooтć $\lambda \lambda \omega$ ' is an official authoritative sending.

21 'ámооте́ $\lambda \lambda \omega$ ' Christ sent: Luke 4:18; John 5:36, 6:29; Sender: Luke 9:2; John 17:18; Spirit sent: 1Peter 1:12; Galatians 4:6; Sender Acts 10:20 and 'тв́ $\mu \pi \omega$ ' Christ sent: John 5:23, 7:18, 8:29; Sender: Jn.15:26; Spirit sent: John 14:26; 15:26; Sender: Acts 13:4.

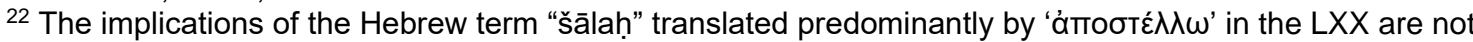
considered further in the scope of this article. The continuity and discontinuity, limitation and transference argument sustained by Harnack, Rengstorf or Müller, Brown are not developed.

23 Matthew 10:40; John 3:34, 6:57, 17:3, 8.

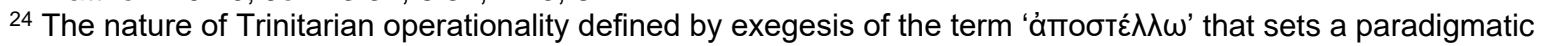
framework for understanding divine action is in the scope of a part two article on this thematic.

25 Isaiah 45:23, 46:10, 55:10; Ezra 1:1-2; Luke 4:17-21; Romans 5:8.

26 ' $\pi \varepsilon \dot{\varepsilon} \mu \omega \omega$ ' in participle mood represents 27 of 32 mentions in the New Testament.

${ }^{27}$ See also John 8:16 where Jesus demonstrates the ' $\pi \varepsilon \dot{\mu} \pi \omega$ ' sending correlation with presence-accompaniment.
} 


\section{The Primary Supposition}

On the grounds of ontological intra-Trinitarian apostolicity, of which the significance of apostolic etymology is critical, this supposition argues that, according to scriptural witness, the three Persons of the Trinity share the same attributes in perfect measure and can and do perform the same causal and medial functions, perfect in nature, operation and relationship. ${ }^{28}$

Apostolic language has been used by proponents of the subordinate-authority-submission hypothesis of the Father-Son in economy and in eternal relationship. Cowan (Ware, Starke, 2015: 49) for example, advocates that "the gospel's language of sending and the accompanying actions of the one sent clearly seem to imply the Son's subordination to the Father who sent him." The proponents of this view suggest, "(as the) Father sends Son and Spirit therefore ... (they) are subordinate to the Father. No one sends the Father; therefore, the Father is not subordinate to anyone. The Son and the Spirit send each other; therefore, ... (they) are subordinate to each other" (Ware, Starke, 2015: 210-11).

The subordinate-authority-submission hypothesis is antithetical to the primary supposition. This inevitably results in weakening or deforming the human-divine apostolic nature of Christ, the Personhood of the Spirit, and the apostolic relationality of the Father. This article argues that apostolicity reveals the simple beauty of the interrelatedness that transcends being and function, opening one's eyes to the Tri-Unity ... 'Oneness' of being in unity, relating and operating, whereby inseparability and indivisibility prevail (Henderson, 2019: 72).

\section{Six attributes of Apostolicity}

John chapter five verse seventeen to thirty reveals a synthesis of expressions which give substance to the supposition that the origin of apostolicity is the Trinity; concordant with the etymological principles, six core attributes of intra and extra-Trinitarian relationship emerge (Henderson, 2019: 69-120). While the exposition focuses upon the Father-Son apostolic relationship, the Spirit is identifiably integral with these principles. These texts read without apostolic understanding will inevitably lead to a subordinate and humanized view of the Son, undermining his divine qualities and relationships. This response is therefore a critical ontological apostolic construct.

\section{1) Collaboration}

"This Father of mine till this present time is at work and I likewise am at work" (John 5:17 TLT)29 raises the question how do two Persons, in perfect equality relate? The equality in attribute and relationship that scandalised the Jews, advocates an accepted ontological and apostolic premise of two equals and oneness. Gill (2012: 3083-84), quoting the Syriac and Arabic versions, reads " ... in conjunction with him, as a co-efficient cause in the works ... (he adds) to be of the same nature, and have the same perfections, and do the same works ... assuming a co-operation with him in his divine works." The postulation of a "collaborative relationship of 'complicity among Perfects' is therefore the only possibility to remain faithful to the fundamental nature of Trinity" (Henderson, 2019: 72).

The collaborative relationship is revealed as the Father mediates the Son and the Son mediates the Father, "... all that the Father gives Me will come to Me ... No one can come to

\footnotetext{
28 Tertullian consistently affirms this ontological unity in Trinity both in substance and in relationship, echoed in

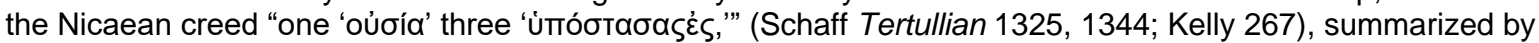
Athanasius, "The Godhead, according to this conception, exists eternally as a Triad of Persons... sharing one identical and indivisible substance or essence. All three Persons, moreover, are possessed of one and the same activity" (Kelly 271).

29 'TLT' Transliteration from the Greek text by the author.
} 
Me unless the Father who sent Me draws him ... No one comes to the Father except through Me." 30 The collaboration transposes the believer into the middle of the ontological-apostolic Trinitarian relationship. The believer sent to Christ, and to the Father is understood as normative apostolic relationship.

If the collaborative relationship characterises divine apostolicity, then the subordinate tension should be resolved, as the words of Jesus exemplify,

\begin{abstract}
Whenever you might lift up on high the Son of man ... you will know by personal experience that I Am, and out of myself I produce nothing but in proportion to what the Father gives me these (things) I speak ... what therefore I, I say in the same measure as the Father said to me, in this same manner I speak. (John 8:28; 12:50 TLT)
\end{abstract}

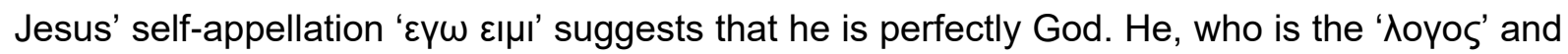

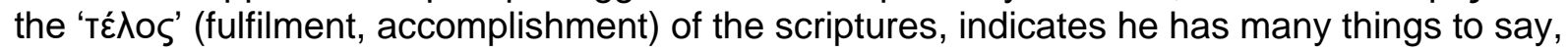

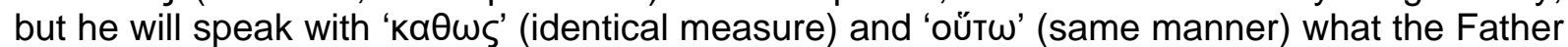
says; that being perfectly God, he will not act 'ámó' His own resource; likewise, the Spirit, original inspiration of scripture, who probes the depths of God, speaks the words that Christ taught. ${ }^{31}$ If the perfect shared attribute of omniscience is accepted, the interrogation no longer concerns divinity, instead, relationality and therefore apostolicity. Jesus sent to speak, speaks out of the divine unity of Persons, a refusal of Jesus, the Spirit and the Father to speak outside of ontological and operational collaborative unity. The two sentences therefore do not require a subordinate tension, they are perfectly resolved in the collaborative relationship, characteristic of divine apostolicity. There is little or no distinction based on works in the

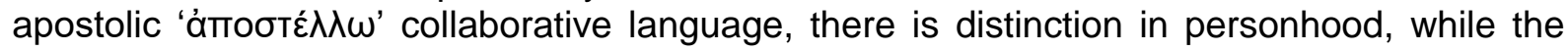
works only find meaning through the apostolic and ontological inter-relationship.

\title{
2) Entire Dependency
}

... the Son is absolutely not able to produce sourced in Himself, ... if not this, (that) He might see the Father producing because that whatever He might produce, these also this Son likewise and equally produces. (John 5:19 TLT)

How can Jesus-Christ who is perfectly God, who has all authority, is the perfect revelation of the Father, holds all judgment, and freely comes of his own accord, ${ }^{32}$ describe himself relationally with the Father in these terms? At a first reading the text seems to suggest that

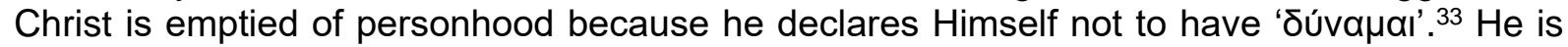
therefore incapable of acting upon his own means and initiative, requiring the leadership and resources of the Father, simply reproducing his thoughts, actions, will or power, as other passages might concur, "... not my will ... not my teaching ... as I hear I judge ... I come not of my own accord ..." 34 Evidence, might lead to the deduction that the Son is in a relationship of subordinate dependency with the Father, and could clearly put into question his divinity and his nature as God-Man, as in Arianism (Bettenson, 1963: 39-44). ${ }^{35}$

\footnotetext{
30 John 6:37, 44; 14:6, see also John 17:9-10 (NKJV).

${ }^{31}$ Acts 2:17; 1 Corinthians 2:10-11; Hebrews 4:12; 2 Timothy 3:16; John 14:26, 16:13.

32 John 10:17-18, 5:27; Matthew 11:27; John 3:31.

33 'סúvauaı' refers to inherent ability power or ability.

34 Will: John 6:38; Teaching, Word: John 7:16, 12:49, 14:24; Judgment: John 5:30; 8:16; Coming: John 7:28.

${ }^{35}$ Arius' letter to Eusebius outlines his view: God existed without beginning, therefore before the Son who has not part in the unbegotten, nor derived from the same substance, "He is from what is not." The Son having beginning is created or begotten, a work of God, capable of good and evil. The Dedication Creed (341 AD) during Constantine's reign corrected, as the Nicene Synod anathematised (325) him, although he found favour in the Eastern Church. Bettenson, H, Documents of the Christian Church, 39-44.
} 
Dependency should be understood in the light of consubstantiality of the Son with the Father. Christ's equality, co-eternity, in substance and relationship within the Godhead expresses the collaborative 'complicity between Perfects'. Barnes (1974: 3085) affirms, "from the necessity of his nature, ... the intimacy of the union ... there is no separate action - no separate existence; but, alike in being and in action, there is the most perfect oneness." On the other hand, Lightfoot (2013: 3094) maintains the subordinate clause "according to the will and prescription of his Father..." while Calvin (1958: 3085) distinguishes the preincarnate eternal Son with the earthly Son, "only to the Son of God, so far as he is manifested in the flesh" for subordinate understanding.

The answer is found in the contextual and interpretive framework of the ' sending. If this facet of apostolicity emphasises relationship and accompaniment, then the context portrays inseparability. The use of the preposition 'ámó' witnesses that Christ does not relate or operate out of himself; in view is a refusal to act outside of the Father-Son relationship, reflecting ontological unity. The 'separation' meaning strengthens the refusal to function separately. The ' $\pi \varepsilon \dot{\varepsilon} \mu \pi \omega$ ' apostolic sending asserts it is only as the indivisible and inseparable Trinity that Christ operates. This demonstrates that the ontological and apostolic should have primacy over the economical and functional because the former defines the nature of the latter.

The relationship of apostolic dependency substantiates the divinity of Christ, in full likeness of the Father. Christ producing whatever the Father produces draws its meaning from the perfect divine resources in Trinity relationality, enhancing Christ's collaborative operation, through the dependency analogies. This apostolic reading resolves the tension and defines the dependency in nature and (re)source.

\section{3) Revelation}

Because this Father loves the Son, and everything He shows him that $\mathrm{He}$ himself produces and works greater than these He will show Him in order that you might wonder with amazement ... no one knows the Son except the Father; nor does anyone know the Father except the Son, and anyone to whom the Son wills to reveal Him. (John 5:20 TLT; Matthew 11:27 NASB)

If the relationship of ' $\varphi ı \lambda \varepsilon \omega^{\omega}$ ' love is a reciprocal, knowing and being known experientially, it implies complicity, partnership and identification with the other in a bond of voluntary

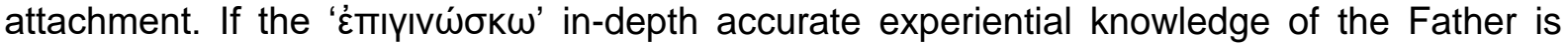
unique, then the revelation will reflect that perfection. ${ }^{36}$ "He who has seen me has seen the Father..." demonstrates, the perfection in relationship and the perfect extent of revelation given, "as God shows him all that he does, he must be possessed of omniscience, for to no finite mind could be imparted a knowledge of all the works of God" (Barnes, 1975: 3085). The 'greater' works that amaze, reflect the perfection in relationship and in revelation, manifest in perfect disclosure, comprehension and demonstration. ${ }^{37}$ This knowing and revealing relationship exists reciprocally between all three Persons, the One revealing the other, demonstrating the quality of omniscience of each other, ${ }^{38}$ a "glorious consciousness, will, and love, of which the Persons themselves are the proper Objects" (Jamieson, Fausset, Brown, 1961: 3085). The revelatory, omniscient, intra and extra-Trinitarian relationship defines the nature and purpose of apostolic sending.

\footnotetext{
${ }^{36}$ Scripture gives witness to a general principle and order of relationship and revelation as witnessed by Abraham (James 2:23; Genesis 18); Moses (Exodus 33:11); Peter (John 21:1-9); the disciples (John 15:13-15).

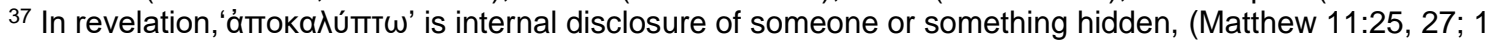
Corinthians 2:10; compared with ' $\delta \tilde{n} \lambda$ os' which is revelation as internal comprehension (1 Corinthians 15:27; 2 Peter 1:14; Hebrews 9:8) and ' $\varphi$ avepó $\omega$,' revelation by tangible manifestation or demonstration (2 Corinthians 2:14, 3:3; Colossians 1:26-27).

381 Corinthians 2:10-12; John 3:34-35; 6:63; 16:12-15; Ephesians 1:7.
} 


\section{4) Unity, Equality and Honour}

Because even as however much this Father raises the dead and produces life in this same manner also this Son to whom he actively desires He produces life ... all the judgment $\mathrm{He}$ had given to the Son; in order that all honour the Son, to the proportion they honour the Father ... even as however much this Father possesses life in Himself, in this same manner He gave also this Son life to possess in Himself. (John 5:21-23, 25-26 TLT)

These three principles respond to the question, what is the relational framework to intraTrinitarian apostolicity? The first assertion is the equality in being and function of the Father and the Son, "... even as however much ... in this same manner ..." emphasise the exact resemblance, that one operates identically as the other, a likeness that is substantiative. The Father causes resurrection and regenerates life, as does the Son, furthermore, the Holy Spirit is also cause and generator of life, in his person. ${ }^{39}$ In the words of Gill (2012: 3092), "the Son has life in himself, essentially, originally, and inderivatively as the Father has, being equally the living God, the fountain of life, and donor of it." Therefore, any notion of mediating the life of the other is foreign to this thought; it is direct relationship to Trinitarian life, manifest in apostolic sending. The three are equally, ontologically and functionally causal generators and ministers of Life. The attribution of a specific function to a specific person fails to adequately discern the nature of Trinitarian collaborative and apostolic life.

Jesus explains unity and oneness with the Father by employing the concept of 'union'. To speak of union, he is not adding something to Himself that he does not already fully possess, rather he is expressing the profound nature of this unity and oneness. ${ }^{40}$ In Clarke's (1967: 3088) view, "the Father acts not without the Son, nor the Son without the Father; their acts are common, their power equal." The purpose of the works, according to Jesus, is found in the Father who apostolically operates them collaboratively, not to attest his divinity, rather his union relationality with the Father. ${ }^{41}$

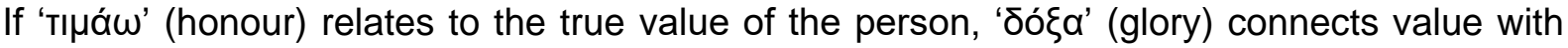
pre-eminence. Jesus possesses eternal glory, distinct from the Father's. Neither the Father, nor the Son, nor the Spirit declare their own glory, they only accentuate that of the other in an apostolic culture of continual reciprocal and mutual glorifying and honouring, beyond function and operation. ${ }^{42}$ The purpose of function is subjugated to the apostolic purpose of mutual glory. The honour relationship is demonstrated by the 'two or three principle'. ${ }^{43}$ The Eastern church fathers perceived this through reciprocal revelation in relation to the ' $\mathrm{\varepsilon} v \mathrm{ov}^{\prime} \omega$ ' of Christ, as the Son reveals the Father, as the Spirit reveals the Son; each one authenticating the veracity of the other.

If in the kenōsis of the Son the Person appeared to men while the Godhead remained hidden under the form of a servant, the Holy Spirit in His coming, while He manifests the common nature of the Trinity, leaves His own Person concealed beneath His Godhead. (Lossky, 1991: 168)

\footnotetext{
${ }^{39}$ Of the Father: Luke 20:38; Romans 4:17; 9:26; 1Timothy 4:10, 6:13; of the Son: John 11:25-26, 14:19;

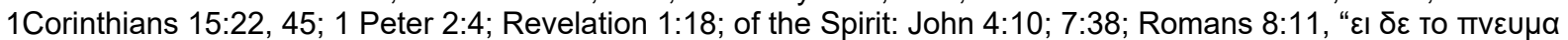

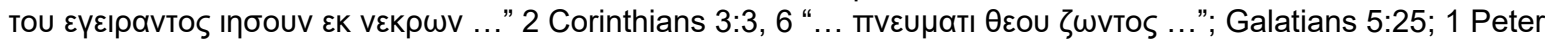
3:18.

40 John 6:46, 8:19, 42, 3:34, 14:16-17, 26, 16:7, 10:38.

41 John 14:10-11, 8:19, 29, 10:38, 14:7; Philippians 2:7.

42 The reciprocal ontological glorifying is supported through use of the passive voice and participle mood.

${ }^{43}$ Of authenticating witnesses for example: Deuteronomy 19:15; Matthew 18:20; 26:60; 1 Corinthians 14:29; 1 Timothy 5:19; 1 John 5:5-8.
} 
The apostolic 'ámoбтर́ $\lambda \lambda \omega$ ' sending is expressed in the self-revelation, ${ }^{44}$ while in the apostolic ' $т \varepsilon \dot{\varepsilon} \mu \omega$ ' sending, the reciprocal revealing authenticates the apostolic inseparability of equality and unity between Father, Son and Spirit. This apostolic oneness cannot be adequately

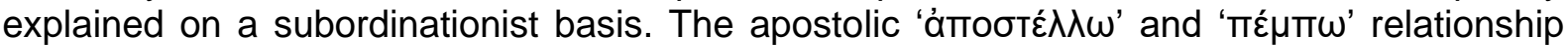
concords with mutual authentication for the purpose of ontological glory and honour. ${ }^{45}$

\section{5) Total Delegation}

Because even the Father judges no one, nothing, but all the judgment He had given to the Son ... Because even as however much this Father possesses life in Himself, in this same manner He gave also this Son life to possess in Himself and authority He gave to Him also to produce judgment ... Absolutely not inherently capable Myself to produce out of Myself nothing according to the proportion I hear, I judge; and this judgment of mine is righteous; because I seek not the active desire of $\mathrm{Me}$, but the active desire of this One sending Me. (Jn.5:22, 26-27, 30 TLT)

If all things, ${ }^{46}$ every person, ${ }^{47}$ all judgment, ${ }^{48}$ all authority, ${ }^{49}$ and all operations ${ }^{50}$ have been delegated, in recognition of the total delegation and Christo-centricity of the Father, how does Jesus respond apostolically to the other members of the Godhead?

1) As to all things, "... however many the Father possesses are mine because of this thing I say that originating out of mine he (the Spirit) will take hold and will declare to you"51 reinforces the perfect delegation of the full measure from the Father, in a sense of mutual ownership with the Son and Spirit. The term ' $\varepsilon$ 'k' means that the Spirit, a perfect, eternal and equal Person of the Godhead lacking nothing, will take out of this substance perfectly delegated, from all that is in the Father and in the Son, he exercises his total delegation for the benefit of believers, as does the Son. ${ }^{52}$

2) Of people, "I have manifested Your name to the men whom You have given Me out of the world. They were Yours, You gave them to Me ... And all Mine are Yours, and Yours are Mine, ... they are in the world, and I am coming to you. Holy Father, keep them in your name, which you have given Me, that they may be one, even as we are one..$^{53}$ Those received from the Father by Christ, are entrusted again to the Father, not in any subordinate manner, instead, those believing are implicitly drawn into a Trinitarian relationship of mutual belonging equally to the Father and to the Son.

3) Of all judgment, "As I hear, I judge ... if I do judge, my judgment is true, for it is not I alone who judge, but I and the Father who sent Me ... the things which I heard from $\mathrm{Him}$, these I speak to the world ... and coming this one (the Spirit) will convict the world concerning sin and concerning justice and concerning judgment..." 54 'All judgment' delegated to Christ, concurrent with the Spirit, is not exercised outside of the Trinitarian relationship but in oneness and unity, whereby the judgment is that of the Godhead.

\footnotetext{
${ }^{44}$ Romans 1:19-20; Matthew 11:27; John 1:4-5, 9-11, 14, 16-18.

45 John $7: 18 ; 8: 50 ; 11: 4 ; 12: 23,28 ; 13: 31-32 ; 14: 13 ; 16: 14 ; 17: 1,5,22 ; 21: 19$.

46 John $3: 35,13: 3$.

47 John 6:37, 39-40, 10:27-28.

48 John 5:22, 27, 17:2.

49 John $5: 27,10: 17-18,17: 2$

50 John 4:34, 5:20, 36, 9:4, 10:25, 17:4.

51 John.16:15 (TLT).

52 The verb ' $\lambda \alpha \mu \beta a ́ v \omega$ ' in the middle voice indicates mutual operation.

53 John.17:6, 10, 11 (NKJV).

54 John 5:30; 8:16, 26 (NASB), John 8:26; TLT John 16:8 (ESV).
} 
4) Of all authority, "For I have not spoken on My own authority; but the Father who sent Me gave Me a command, what I should say and what I should speak" . Jesus' having all authority does not speak ' $\varepsilon \xi$ عautou' that is an authority that has its origin in Himself. ${ }^{5}$ In the same manner the Spirit, endorsed by the assertion, "He ... the Spirit

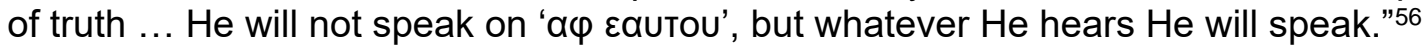

5) As to all operations, "Do you not believe that I am in the Father, and the Father in Me?

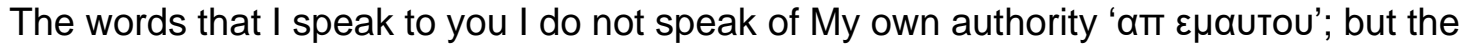
Father who dwells in Me does the works." 57 Having "all authority" the divine persons refuse to operate out with the relationship of oneness in the framework of apostolic relational unity and collaborative operation.

Delegation therefore, intimates perfect mutuality, whereby the emphasis is not upon the individual person in the Trinity, rather it reflects the depth of oneness in ontological and apostolic relationship and operation. The mediatory must find herein its insubordinate meaning, "it is in him as it is in God. He has the control of it, and can exercise it as he will ... equal in omnipotence to the Father, and the power of searching all hearts - equal in omniscience to God" (Barnes 1976: 3092; Gill, 2012: 3093). Apostolically, delegation will never be singular but plural, and in that the indivisibility of the Godhead in operation directs one to the ontological significance of the collective apostolic ministry of the Trinity in favour of the believer.

\title{
6) Full Autonomy
}

\begin{abstract}
Because even as however much this Father raises the dead and produces life in this manner also this Son to whom he actively desires He produces life ... Because even as however much this Father possesses life in Himself, in this same manner He gave also this Son life to possess in Himself. (John 5:21-22, 26 TLT)
\end{abstract}

Apostolic autonomy is expressed in the Son as not only possessing the same measure in perfection and fullness, but also being causal and generating source-giver of divine life in and of Himself, equally and substantially, just as the Spirit. ${ }^{58}$ Belief in the Son and in the Father is into everlasting life, whereby the eating and drinking of Christ is reciprocal union, which enjoins the fountain source of the Spirit in the production of Trinitarian life. ${ }^{59}$

This ontological consubstantiality, unites the individuality and functionality of the three persons autonomously as divine sources of the one divine life. Apostolicity affirms the perfect nature and potential to operate as equal consubstantial sources. The apostolic sending designates the divine 'living' persons in a relationship of interrelatedness for the one purpose of communicating divine life to the believer.

Apostolic autonomy of divine will, addresses the subordination suspected in the words "... Father, not my will but yours" 60 which seems to indicate that Jesus submits entirely to the Father's will. Grudem (Ware, Starke, 2015: 40, 57) asserts that even if the, “... Son's submission to Father's leadership is only for his time on earth ... the Father ... initiates and leads, and the Son is the one who carries out the will of the Father," implying that the Son does not have a will of his own, but relates only to that of the Father. Cowan $(2015: 40,57)$ similarly

\footnotetext{
55 John 12:49 (NKJV).

56 John 16:13 (NKJV).

57 John 14:10 (NKJV).

58 John 4:14; Romans 8:2, 10; Galatians 6:8.

59 John 6:35, 51, 53-57, 63.

60 Matthew 26:39, 42.
} 
talks of harmonisation that is obedient. Jesus witnesses that it is the Father's will and pleasure, ('عủסokía') to reveal Himself, but that revelation and the will to reveal has been attributed to the Son, anchoring the will of the Father in Christ Jesus. Christ is cause and agency through whom the divine will is manifest, "No one takes it [my life] 'ámó' (sourced in) me, but I lay it down of 'ámó' my own accord. I have authority to lay it down, and I have authority to take it up again"61 exemplifies this. Jesus demonstrates absolute authority over Himself as to what He does with his life, not in obedience to the Father's will but from his own autonomous Self. This autonomous exercise of will is the charge of the Father. When he says, "Father not My will but yours," he is reflecting a conscious uniting of His will with the Father's to such perfection that it becomes as one. ${ }^{62}$ What is demonstrated in apostolic autonomy, from the one who has his own will, is not that his will is annulled; but it is the hypostatic will of the person of the Son united perfectly and indivisibly to the will of the Father as one, manifested operationally by united collaboration in autonomy.

The six attributes summarised, define and expound the nature of apostolicity intra- and extraTrinity, asserting the ontological character and primacy in relationality and operationality of apostolicity as archetypal origin from which emanates all other expressions of that nature:

1) Collaboration of complicity among Perfects that defines apostolic relationality;

2) Entire Dependence where subordination is replaced by apostolic inseparability in relation and in operation;

3) Revelation where the perfection of divine friendship equates to perfect disclosure whereby one reveals the other in apostolic purpose;

4) Unity-Equality-Honour, founded upon substantiative likeness wherein union demonstrates the nature of oneness and authenticates apostolic self-disclosure and reciprocal and mutual revealing relationship, and purpose of honouring and glorifying the other;

5) Total Delegation evidences the Christo-centricity of the Father, to which Christ responds with perfect mutuality in the plurality of united intra-Trinity collaboration;

6) Full Autonomy in perfect measure expressing causal source and agency, framed by an apostolic conscious indivisible and collaborative oneness.

\section{Summary Remarks}

This section draws out some of the critical principles' integral to the development of the historical apostolic view, and measures them against the Trinitarian view of apostolicity, proposing a reinterpretation and reformulation.

Historical discontinuity of the apostolic dilemma required of transference, transformation and succession to provide continuity, through a decisive and historic paradigm shift in the post apostolic era. The discontinuity mutation principle contradicts the unbroken continuity of the apostolic reality that permeates and emanates from Trinity. If apostolicity is inherent in the divine nature, relation, and operation, then every person, word, and action in the Trinity is sent out bearing the same apostolic nature.

New Testament apostolic discontinuity finds continuity through transference: to canon, to bishops and to episcopate structures. While transference to canon guaranteed the perennity of apostolic teaching and practice, the nature of the canon became an apostolic source; in the words of Jesus, "you search the scriptures because you think that in them you have eternal

\footnotetext{
61 John 10:17-18 (ESV).

62 The same apostolic and ontological qualities should be understood of the Holy Spirit's will. John 3:8; 1 Corinthians 12:11.
} 
life; and it is they that bear witness about me." 63 The scriptures are therefore not source or origin, instead, they are means and agency that lead to the divine ontological source. The

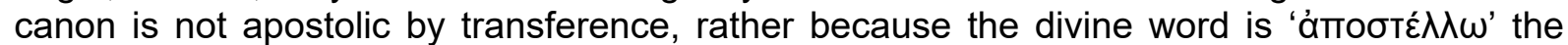
Godhead, it bears the apostolic nature and purpose, in which there is no transference, only continuity.

Transference to canon created the vacuum of apostolic depersonalisation. The apostles became canon, as their 'strict successor' and became source and means of apostolicity. The unique discontinuous characteristic of the twelve apostles was their physical eye-witness experience of Jesus. Pentecostalism's spiritual pneumatological experience transposes the paradigm from historical to ontological, through a normative untransformed and continuous encounter with the same Spirit as the original apostles. The Trinitarian model re-personalises apostolicity, guaranteeing direct apostolic continuity conform to their nature.

Succession through transference and transformation produces distanciation through the mediation of bishop-centricity, central to the episcopate construct. Ordinands, offices and designated functions, have in principle, displaced and replaced the three divine Persons as apostolic senders and comers. Scripture, sacramentalism and religious actions have sought to certify apostolic appellation, however, the means have been confused with source, and praxis with divine nature. With the former, authentic apostolicity is detached from its original source and form, whereas with the latter, the Trinitarian model recentres apostolicity by inverting the source-means-praxis rationale. The performance rituals of succession, is to say, 'I do apostolically therefore I am apostolic'. Conversely, to be apostolic is to experience divine apostolic nature by relational union in Trinity, that through divine means apostolic natured purpose is manifested through unmediated continuity.

Bishop-centricity became a form self-exaltation and means of perennity that is contrary to Christo-centricity, as Cyprian demonstrated. The apostolic Trinity recentres apostolic legitimacy in Christ: Head, Source, Foundation and Means holding the Church together in Himself, ${ }^{64}$ who is the source of purpose in apostolicity. Therefore, Christo-centricity in the eternal Trinity guarantees apostolic perennity. It is an ontological reality that does not require transformation neither transference, nor succession. The divine determination to manifest apostolically is the sole basis for unmediated continuity.

\section{Conclusion}

This article has responded to the research question, what is the origin and nature of apostolicity and how it is demonstrated. It has drawn attention to the absence of Trinitarian theology in the historical construct of apostolicity. The Trinitarian relational paradigm of direct and unaltered continuity challenges the historical model's mechanisms to attain continuity. The authentication of apostolicity has been raised from functional and structural suppositions to find origin, source and agency in eternal Trinitarian being and relationality. All that emerges from Trinity has the intended primary purpose to reveal and demonstrate divine apostolicity.

The significance of apostolicity, as defined by this Trinitarian perspective, is foundational to renewed self-understanding. ${ }^{65}$ It provides paradigm basis for a reinterpretation of apostolicity ontologically, substantiated by Jesus words,

\footnotetext{
63 John 5:39.

${ }^{64}$ Ephesians 4:15-16; Colossians 2:19.

65 Trinitarian apostolicity that defines the nature of operations and the application to believers and to Church lies out with the scope of this article, although part of supplementary writings on the subject.
} 


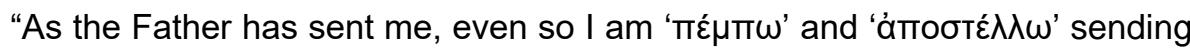
you ... into the world ..."66

\section{References}

Barnes, A. (1976). Barnes' Notes on the New Testament. Kregel, USA: (n.d.), Online, Bible Edition 2015. pp: 3085, 3092, 3095.

Bettenson, H. S. (ed.) (1963). Documents of the Christian Church. Second edition. Oxford University Press. pp. 39-44, 68-68, 73-74, 77.

Boice, J. M. (1975). Foundations of the Christian Faith: A Comprehensive \& Readable Theology. Inter-Varsity Press. p.611

Brown, C. (ed.) (1975). The New International Dictionary of New Testament Theology Vol.1:A-F. Exeter: Paternoster Press. pp.128-129, 132, 135.

Calvin, J. (1958). Calvin's Commentary on the Bible. Online Bible Edition.

https://ccel.org/ccel/calvin/commentaries.i.html (Retrieved 14th June 2021). pp.3085.

Clarke, A. (1967). Commentary on the Bible. Online Bible Edition, 2010. P.3088.

Crossway Bibles. (2004). The Holy Bible English Standard Version (ESV). Wheaton IL: Good News Publishers.

Ferguson, S. B. \& Wright, D. F. (ed.) (1988). New Dictionary of Theology. Leicester: IVP Academic. pp.40-41, 184, 444-45.

Gaebelein, F. E. (1979). The Expositor's Bible Commentary: with the New International Version of the Holy Bible. London: Pickering \& Inglis. pp.633, 635.

Gill, J. (2012). An Exposition of the Old and New Testaments Online Bible Edition. pp.308384, 3092-3093.

Harnack, A. (1962). The Mission and Expansion of Christianity in the First Three Centuries. Grand Rapids MI: Harper Torchbook. www.ccel.org/ccel/harnack/mission.html. (Retrieved $16^{\text {th }}$ November 2018). pp.70-71, 273, 277, 279-80, 284, 286, 289, 294, 296, 334-35, 369-70, 394.

Henderson, E. S. (2019). A Biblical Examination of an Ontological Reading of Theology in Trinity, in the Believer and in Church (PhD Dissertation, Atlantic Coast Theological Seminary, FL, USA. 2019). Doi:10.17913/g8j-ds77. pp.69-120, 72, 79.

Hunter, H. D. (2013). Pentecostal Reflections on Apostolicity Journal of the European Pentecostal Theological Association, 33(1). [Available online at www.academia.edu/3293264/Pentecostal_Reflections_on_Apostolicity.pdf].

\footnotetext{
${ }^{66}$ John.20:21; 17:18, 23 (ESV).
} 
Jamieson, R., Fausset, A. R. \& Brown, D. (1961, 2008). Jamieson, Fausset \& Brown's Commentary on the Whole Bible. Grand Rapids MI: Zondervan Publishing. Online Bible Edition. p. 3085.

Josephus, Flavius. (1987). The Works of Josephus: Complete and Unabridged. Peabody, MA: Hendrickson Publishers. p.776.

Karkkainen, V-M. (2001). Pentecostalism and the Claim for Apostolicity. Evangelical Review of Theology. ISSN: 0144-8153. Vol.25 4 October 2001. Paternoster Periodicals. Available at: theology.worldea.org/wp-content/uploads/2020/12/ERT-25-4.pdf. (Retrieved 14th April 2021). pp.323-336.

Kay, W.K. (2005). Apostolic Networks and Mission Journal of the European Pentecostal Theological Association, 26(2). [Available online at

https://www.academia.edu/41267889/Apostolic_Networks_and_Mission.pdf] (Retrieved 12th April 2021). pp.156-167.

Kelly, J.N.D. (1968). Early Christian Doctrines. Fourth Edition. London: Adam \& Charles Black Ltd, 103911481-J-N-D-Kelly-Early-Christian-Doctrines.pdf. (Retrieved $3^{\text {rd }}$ April 2018). pp.31, 333, 35-36, 38, 47, 267, 271.

Lightfoot, J.B. (2013). A Commentary on the New Testament from the Talmud and Hebraica. Create Space Independent Publishing Platform. Online Bible Edition 2018. p.3094.

Lossky, V. (1991). The Mystical Theology of the Eastern Church. Cambridge: James Clark. Pdf. (Retrieved 16th February 2019). p.168.

McKechnie, P. (2001). The First Christian Centuries: Perspectives on the Early Church. Downers Grove IL: InterVarsity Press. pp.105, 171.

McKim, D. K. (1998). Historical Handbook of Major Biblical Interpreters (ed.., Downers Grove, IL.: InterVarsity Press. p.5.

Tertullian, (160-230ca.). The Writings of the Fathers down to A.D. 325 Latin Christianity: Its Founder, Tertullian. In P. Schaff and A. Menzies (eds. 1885). Vol.3; Ante-Nicene Fathers, Latin Christianity: It's founder, Tertullian. Grand Rapids, MI. Anf03.pdf. www.ccel.org/ccel/schaff/anf03.html. (Retrieved 15 ${ }^{\text {th }}$ May 2019). pp.1325, 1344.

Fathers The Apostolic, (ca.100CE). The Didache: The Lord's Teaching through the Twelve Apostles to the Nations. In J.B. Lightfoot. MacMillan and Co. 1891. [Available online at www.earlychristianwritings.com/text/didache-roberts.html]. (Retrieved 16th November 2018).

The Lockman Foundation. (1985). New American Standard Bible. Thomas Nelson, Inc.

Thomas Nelson, (1994) The Holy Bible, New King James Version. Thomas Nelson, Inc.

Vondey, W. (2017). Pentecostal Theology: Living the Full Gospel. Pdf. New York:

Bloomsbury Publishing Plc. pp.229-230, 234, 244, 249. 
Wand, J. W. C. (1937). A History of the Early Church: To AD 500. London: Methuen \& Co. Ltd. pp.57, 59.

Ware, B. A. \& Starke, J. (2015). One God in Three Persons: Unity of Essence, Distinction of Persons, Implications for Life. Wheaton IL.: Crossway. pp.46, 49, 57, 210-11.

Zodhiates, S. (1993). The Complete Word Study Dictionary: New Testament. Chattanooga, TN.: AMG Publishers. pp.553, 1137. 